\title{
Standardized Organizational Evaluation Based on Quantity, Quality and Effective Evaluation Model
}

\author{
Yan Cui *, Pan Wei \\ China National Institute of Standardization, No. 4 Zhichun Road, Beijing, China \\ *cuiyan@cnis.gov.cn
}

Keywords: evaluation model; organizational evaluation; standardization

\begin{abstract}
This evaluation is based on the measurement model of the system engineering theory and methods, design, and puts forward a standardized organization and based on the quantity, quality, and effective model. Based on this model, the evaluation index system is established. The research shows that throughout this model, the overall evaluation of the work performance of the organization can be achieved with a quantitative approach to support the specialization of experts to achieve a qualitative evaluation, in order to promote organizational evaluation to become more scientific, criterion and standardized.
\end{abstract}

\section{Introduction}

Organization performance evaluation has always been a research task of all countries around the world, along with the progress of time, countless methods of innovations, reciprocating [1-5]. At the moment, the most popular practices around the world are as follow:

\subsection{Management by objectives}

Management by objectives is through the decomposition of the overall objective of the organization down to personal objective, and finally based on the assessment of the completion of the work objectives to assess the performance of the assessment. Before starting the work, the examiner and the person to be evaluated should agree on the work content, deadline, and the criteria for the examination. When the deadline approaches, examiner should assessed based on the working conditions and the original criteria of the examination of the person to be evaluated [6-8].

\subsection{Key performance indicator}

Based on the annual target of the organization, the KPI is based on the analysis of the work performance of the employees [9-10], so as to determine the key quantitative indicator reflecting the comprehensive performance of the organization, department, and employee itself within a certain period of time, and based on this performance evaluation.

\subsection{Rating scale method}

Rating Scale method is according to the work analysis, the assessed positions of work content 
will be divided into several independent modules, in each and every modules uses clear language to describe the work completed to assess the module work standards. At the same time, the standards will be divided into few levels of options, for example "excellent, good, qualified, and unqualified". The examiner will evaluate the person based on their working performance, and will fully evaluate the each and every single module. The overall scores will be the employee's evaluation result [11-12].

\subsection{Balance scorecard}

The balance scorecard evaluates from these four perspective of the organization's financial, customers, internal business processes, learning and growth [13-16], and it gives various weight based on the requirement of the strategy to achieve a comprehensive evaluation of the organization so the management can grasp the overall control of the organization, and lastly to achieve the ultimate strategic goals of the organization.

Furthermore, Balance Scorecard and KPI are the most popular evaluation methods in the country, Balance Scorecard is from Robert Kaplan, a professor from Harvard University and David Norton which is the CEO of Nolan Norton Institute, they proposed in the 1990s and it has become one of the most widely used methods; BSC emphasizes on the four targets such as "customer needs", "internal operations", "learning and growth". But there is still a lack of measurement of technological progress, so the evaluation of operational performance is focus on the result, not on the processes, and there is one-sided.

Based on the "General rules for Science and Technology "of the national standard, this article establishes a measurement standard that are more scientific, objective, and comprehensively reflects the objective of the evaluation target (standard development project) and a QQE measurement model that reflects some common and standard characteristic. Based on this, it constructs a system that can reflect the measurement of these attributes and measure the progress of the target under evaluation. This is the main differences between the evaluation method of this research and the traditional evaluation method.

\section{Establishment of Index System Based on Quantity Performance Evaluation Model}

Data collection is difficult, hard to measure, and the main reason for the difficulty of the evaluation is the traditional management methods are too weak. It is impossible to bring about objectives, reasonable, and reflects the actual situation of the data. "General rules for Science and technology "had just provided us this kind of standard, not only technique, but also measurement and tools of management and innovation. All organizational functions are reflected in the improvement of their working aspect. This evaluation uses the system engineering theory and methods that based on measurement model. Accordingly, the quantity, quality and effective models based on standardized technology are designed and proposed: Quality is to measure the standardization of the organization's main work content related indicators, uses to measure the target of workload and the completion of any others aspects: Quality is to measure standardization of the organization's main work process of the relevant indicators that uses to measure the evaluation target standards of preparation, revision, conversion, promotion management, to ensure the completion of the work process; Effective is to measure the performance of the standardization organization to obtain the relevant indicators for the measurement of the target evaluation in preparation, revision, conversion, promotion to achieve the results, efficiency, and effective. There are three types of indicators that contain some logical relationship: without the quantity input, everything is empty talk; without a quality reflection, we cannot see the implementation of the working performance and responsibility; without effective, all the work done is vain, with no value 
contribution, it is a waste of the organizational resources. Quantity and quality are the premise of efficiency and guarantee; effective reflects whether the quantity and quality serve their purpose and can we achieve our goal. The three tier indicators commonly reflect the overall performance of the evaluation target.

Construct the indicator system of "standardization technical organization evaluation", as shown in Table1. Based on the national standard of "General Rules of Science and Technology", the establishment of organizational evaluation of quantity, quality and effective indicators and its system, analysis the relationship of different kind of quantity, quality, and effective indicators, and establish the functional relationship between the variables and indicators. Also, from the three dimensions of quantity, quality and effective of the organization's performance analysis and evaluation, according to the quantitative indicators of the objective data to fully reflect the organizational performance and innovation.

\section{Data Analysis}

This topic randomly picked 10 standardized organizations (hereinafter referred as TC) the data from year 2013 to year 2015, with small quantity of data analysis, trial calculation, verification of compliance and feasibility. When collect more data for secondary checking, verifications, and analysis of the logic and relevance of the calculation result, the estimated range or error and acceptable level. Lastly, conduct all the data processing, analysis, calculation, and based on the calculation result, given out the final sort and the evaluation conclusion.

\subsection{National professional standardizations technical committee to measure the overall situation}

During the period year 2013 to 2015, the overall performance of 10 national professional standardization organizations is showed in Figure 1. Figure 1 showed that, during the evaluation period, the operating performance showed an increasing trend with a sharp year to year increase. The final overall operating performance improvement was at $27 \%$, where the three dimensions which is the quantity, quality and effective had increase $29.71 \%$, 34.72\% and $23.14 \%$ respectively. Among them, the "Quality" increasing rate is larger, and the "Quantity" is in the middle, and "Effective" had the smallest increase in trend. This show that from the period of year 2013-2015, the 10 national professional standards organization bodies had improved in the operational performance that mainly came from the contribution of the "work process" completion indicator. Furthermore, from the data we know that the 10 evaluated standardization organizations have substantially improved their working abilities in the aspects of training frequency, organization's service capability, international standardization work, winning rate, and standard maintenance rate. Thus, this also reflects from the side that the technical committee actively promoted the publicity and implementation of national standards, international standardization and project application, this urge the implementation of national standards and the bringing in and out of the national standards.

From year 2013-2015, the performance of 10 standardization organizations changes are shown in Figure 2. In Figure 2, the axis of abscissa represents 10 standardization organizations and the ball shape represents the name and growth rate of the standardization organization.

From Figure 2, we can see that the operating performance of the five standardization organizations has increased by an average of 205.74\% (range from 6.76 692.86\%); The operating performance of the five standardization organizations decreased by an average of $-12.24 \%$ (range from, 0.72 to $31.56 \%$ ); Overall is increasing trend; where it is consistent with the general trend. From the radar chart of growth rate (Figure 3), the two level of differentiation are vital, which shows that the development speed of each standardization organization is imbalance. Through analysis, the reasons are as below. The performance of individual standardization organization 
didn't significantly improve because the organization itself didn't locate and analyze their own weaknesses, and didn't find a way to break through. Therefore, throughout this evaluation, we can help different standardization organizations to recognize the bottleneck of the own development, analyze and solve the problems. At the same time, it can also facilitate the comparison among different organizations, look for the gaps between themselves and other organizations, learn from experience and facilitate the common development of different standardization organizations.

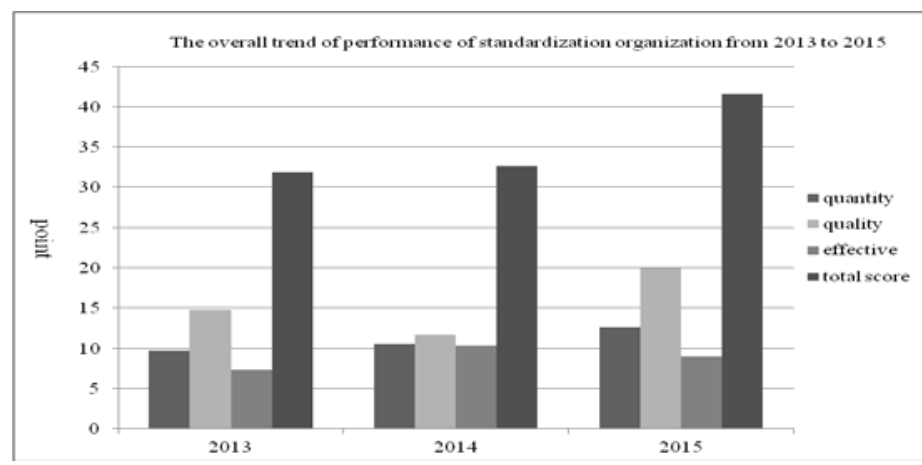

Figure 1 2013-2015 overall performance of operational performance

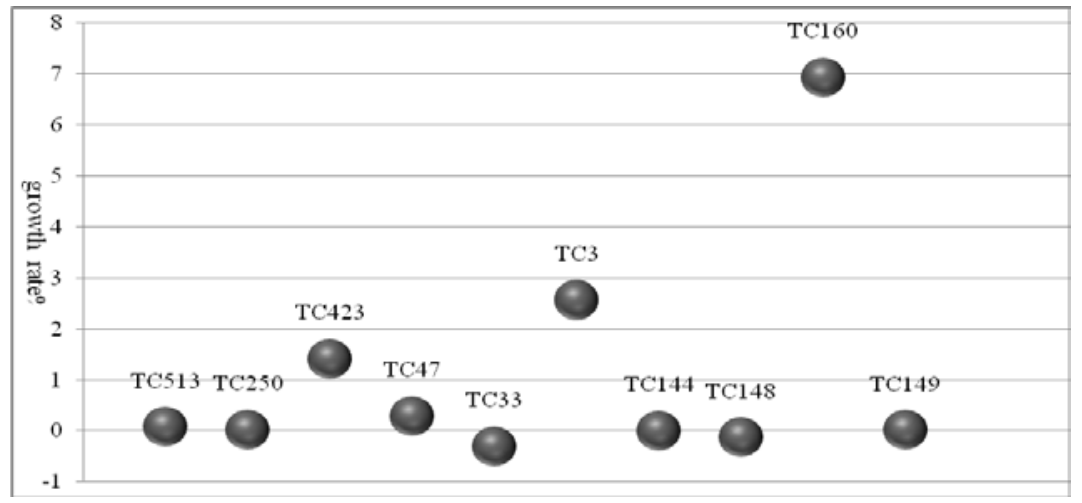

Figure 2 Three years operational performance growth distribution

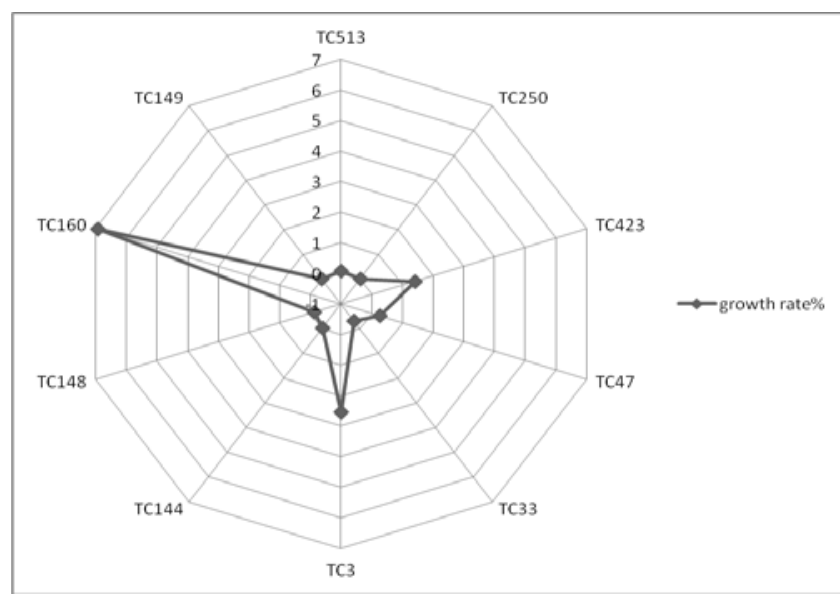

Figure 3 Growth rate radar chart

\subsection{Key indicators of data collecting}

By analyzing the data from 10 TCs, we chose the three indexes of "leading development of international standard rate", "participating in international standard rate "and "project completion 
rate "for in-depth data analysis. We found out that the "Leading development of international standard rate" have four TCs in this score, which involve in the pilot institution 40\%; the "participating in international standard rate" have five TCs in the score, which involve in the pilot institutions 50\%; These two indicators are relatively large, fully reflects the transformation from "bringing in" to "going out". From the standard side, it reflected that our country had improved for the overall innovation capability. From "following" to "leading" the process will be very slow. The indicators scores already reflected this reality.

Figure 5 "Project completion rate" is currently the only "effective" indicator, out of 15points, 7 of the TCs score more than 8 points, as well as there are rooms for improvement, this also reflects the professional standardization organizations in the project Research \& Development capabilities are still very high potential. Because of this evaluation's data source is limited, the effective indicator can only be set up one, and so the proposed performance evaluation in the future is to increase the reporting requirements that are related to the effective of the data in advance to enhance the effective of the performance appraisal-oriented efforts.
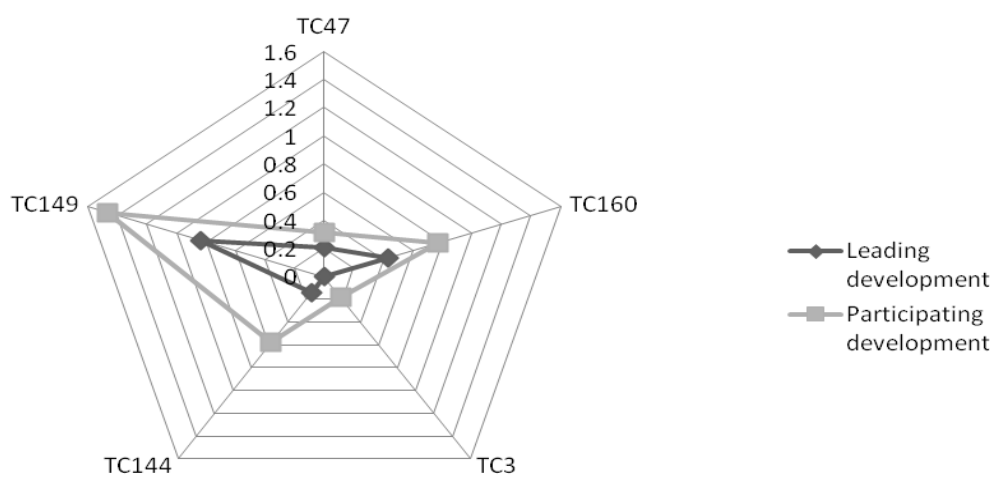

Figure 4 leading (participates) the international standards setting score distribution radar chart

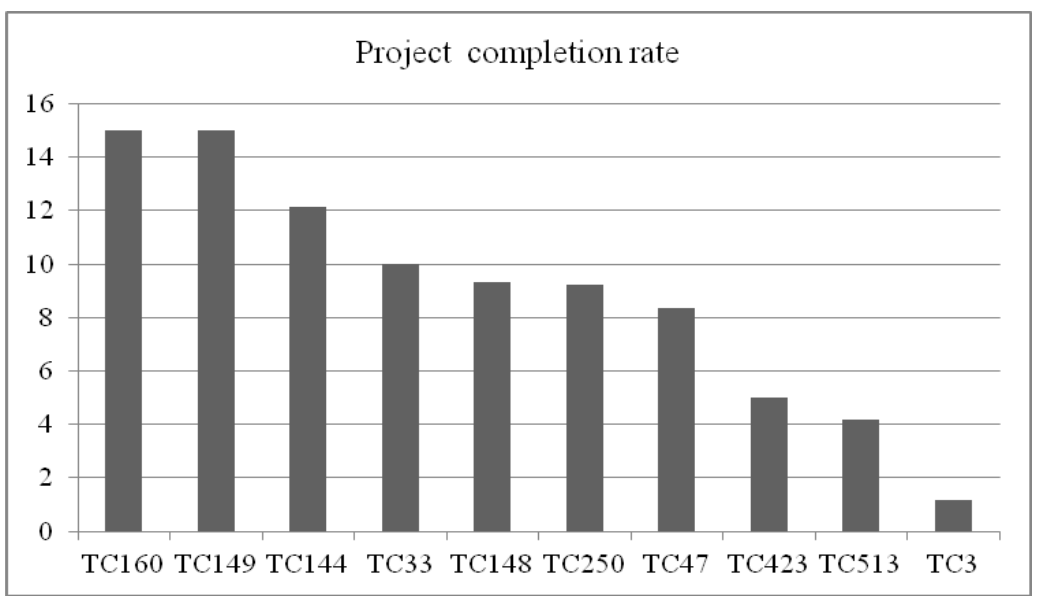

Figure 510 standardization technical organizations project completion rate score

\section{Conclusion}

This paper proposed the evaluation model of quantity, quality and effective standardization technology organization, assists the professional expert qualitative evaluation by quantitative 
method and promotes the scientific organization, standardization and organizational evaluation standard. We improve the evaluation of organizational structures and the performance appraisal mechanism through the use of modern technical methods of standardization, quantification, visualization and information. We will enhance the scientific and modernization of organization structures and brings organization to reform and increase the innovation performance.

\section{Acknowledgement}

This paper is sponsored by the Presidential Foundation "Evaluation index system optimization and data model research of national professional standardization technology committee" $242018 Y-5972$.

\section{References}

[1] R.S. Kaplan, D. P. Norton. Harvard Business Review, Jan./Fed.1992.

[2] Wilcox M, Bawne M. (2003), Predicting performance. Management Decision, 41(8): 806

[3] Kaplan R.S. (2001), Strategic performance measurement and management in nor-profit organization. Non-profit Management \& Leadership, 11(3):353-370

[4] Patton M. (2010), Utilization-focused evaluation,4th edition. New York: SAGE publications Inc.

[5] Dibb S,Quinn L. (2010), Debate: Research impact or career progression. Public Money \& Management, 30(6):326-328

[6] LUO Biao, MIAO Ran, WENG Qingxiong. (2014), Improve MBO Effectiveness ---Empirical Study Based on Different Types of Organizational Culture, soft science, 28(2):83

[7] Qiu Guodong, Wang TAO, (2013), A rethinking on Drucker's management by objectives ---A postmodern perspective, Academic monthly, 45(10):21

[8] ZHOU Dian, ZHANG Xinshu, DU Peng-fei, et al. (2014), Theory and Practice of Management by Objective of the Comprehensive Hospital, Chinese Hospital Management, 34(3): 18-20

[9] XU Fen, KANG Qi, WANG Ning, et al. (2014), Constructing the Index System of Performance Evaluation for Community Health Service Institutions Based on KPI Principle, Chinese General Practice, 17(25):2937-2938

[10] ZHAO Chuan, YE Hua, Construction of Key Performance Indicators(KPI)in Dispatching Operation, Proceedings of the CSU-EPSA,27(5):98.

[11] WEI Guang qiong, (2014), Application of Rank Correlation in Bid Assessment of Comprehensive Evaluation, Construction\& Design for Project, 160

[12] N. Rodríguez-Padial, M. Marín, R. Domingo, (2015), Strategic framework to maintenance decision support systems, Procedia Engineering, 132: 903 - 910

[13] Kaplan, R. S., and Norton, D., (1996), Using the Balanced Scorecard as a Strategic Management System, Harvard Business Review, January-February,75 85

[14] Kaplan, R.S., and Norton, D., (1996), The Balanced Scorecard: Translating Strategy into Action, Harvard Business School Press.

[15] Kaplan, R.S., and Norton, D., (1992), The Balanced Scorecard-Measures That Drive Performance, Harvard Business Review, January-February,71 79

[16] Lam, C. K., and Ren, Q.S., (2003), The BSC-Oriental TQM Model, conference Paper Published in the Tenth Hong Kong Quality Management Convention. 
Table 1. Standardization technical organization evaluation index system

\begin{tabular}{|c|c|c|c|c|}
\hline classification & Name of Indicator & Indicator calculation & Weight & Indicator description \\
\hline \multirow{7}{*}{$\begin{array}{l}\text { Quantity } \\
50 \%\end{array}$} & $\begin{array}{l}\text { Included the national } \\
\text { and standard rate plan }\end{array}$ & $\begin{array}{c}\text { Included the national, number } \\
\text { of standard rate plan/ past } \\
\text { national standard number of } \\
\text { project }\end{array}$ & $10 \%$ & $\begin{array}{l}\text { reflect the development } \\
\text { project }\end{array}$ \\
\hline & $\begin{array}{l}\text { review of completion } \\
\text { rate }\end{array}$ & $\begin{array}{l}\text { Complete review criteria / } \\
\text { review criteria should be } \\
\text { completed }\end{array}$ & $4 \%$ & $\begin{array}{l}\text { Reflect the daily work } \\
\text { efficiency }\end{array}$ \\
\hline & $\begin{array}{l}\text { International standard } \\
\text { voting rate }\end{array}$ & $\begin{array}{c}\text { International standard voting } \\
\text { rate }\end{array}$ & $3 \%$ & $\begin{array}{c}\text { Reflecting the participation } \\
\text { in the voting international } \\
\text { standard situation }\end{array}$ \\
\hline & $\begin{array}{c}\text { national standard } \\
\text { convert into } \\
\text { international standard } \\
\text { proposal rate }\end{array}$ & $\begin{array}{l}\text { The number of international } \\
\text { Standard Proposal / Current } \\
\text { Number of national standards }\end{array}$ & $7 \%$ & $\begin{array}{c}\text { Reflects the leading role of } \\
\text { participation in international } \\
\text { work }\end{array}$ \\
\hline & $\begin{array}{l}\text { leading the } \\
\text { development of } \\
\text { international standard } \\
\text { rate }\end{array}$ & $\begin{array}{l}\text { The number of undertaking } \\
\text { the international standards/ } \\
\text { the current number of national } \\
\text { standard }\end{array}$ & $12 \%$ & $\begin{array}{c}\text { Reflect the component of } \\
\text { participation in international } \\
\text { work }\end{array}$ \\
\hline & $\begin{array}{c}\text { Participate in } \\
\text { international standard } \\
\text { rate }\end{array}$ & $\begin{array}{l}\text { The number of participating in } \\
\text { international standard/the } \\
\text { current number of national } \\
\text { standard }\end{array}$ & $7 \%$ & $\begin{array}{l}\text { Reflect participation in } \\
\text { international work }\end{array}$ \\
\hline & $\begin{array}{l}\text { Review the standard } \\
\text { voting rate }\end{array}$ & $\begin{array}{l}\text { The number of voting } \\
\text { committee/ the total number } \\
\text { of committee }\end{array}$ & $7 \%$ & $\begin{array}{l}\text { Reflect the work load of } \\
\text { standard committee }\end{array}$ \\
\hline \multirow{5}{*}{ Quality 35\% } & Training times & Training times & $5 \%$ & $\begin{array}{l}\text { Reflect the standard } \\
\text { promotion }\end{array}$ \\
\hline & $\begin{array}{c}\text { The number of service } \\
\text { businesses }\end{array}$ & $\begin{array}{c}\text { The number of service } \\
\text { businesses }\end{array}$ & $5 \%$ & $\begin{array}{l}\text { Reflect the work of standard } \\
\text { committee services }\end{array}$ \\
\hline & $\begin{array}{l}\text { International standard } \\
\text { conversion rate }\end{array}$ & $\begin{array}{l}\text { Converted national and } \\
\text { standard /(number of } \\
\text { International standard } \\
\text { counterparts- unsuitable } \\
\text { conversion quantity) }\end{array}$ & $8 \%$ & $\begin{array}{l}\text { Reflect the transformation of } \\
\text { the standardization of the } \\
\text { work of international } \\
\text { standard }\end{array}$ \\
\hline & Winning amount & $\begin{array}{c}\text { Winning amount(province, } \\
\text { unit, industry above) }\end{array}$ & $10 \%$ & $\begin{array}{l}\text { Reflect the working standard } \\
\text { of the committee }\end{array}$ \\
\hline & $\begin{array}{l}\text { Standard maintenance } \\
\text { rate }\end{array}$ & $\begin{array}{l}\text { The number of national } \\
\text { standards under study / the } \\
\text { current number of national } \\
\text { standards }\end{array}$ & $7 \%$ & $\begin{array}{l}\text { Reflect the sustainable } \\
\text { development of the standard } \\
\text { committee }\end{array}$ \\
\hline $\begin{array}{l}\text { Effective } \\
15 \%\end{array}$ & $\begin{array}{l}\text { Project completion } \\
\text { rate }\end{array}$ & $\begin{array}{l}\text { Actual number of completed } \\
\text { projects / Number of projects } \\
\text { that should be completed }\end{array}$ & $15 \%$ & $\begin{array}{l}\text { Reflect the completion of the } \\
\text { standard target }\end{array}$ \\
\hline
\end{tabular}

